Beata Krawczyk-Bryłka

Politechnika Gdańska, Polska - Gdańsk University of Technology, Poland

PAWEt ZIEMIAŃSKI

Politechnika Gdańska, Polska - Gdańsk University of Technology, Poland

Michat T. TOMCZAK

Politechnika Gdańska, Polska - Gdańsk University of Technology, Poland

KatARZyna StankieWicz

Politechnika Gdańska, Polska - Gdańsk University of Technology, Poland

\title{
Zasada szalonego patchworku - efektuacja jako inspiracja do kształtowania relacji i postaw biznesowych
}

\section{Crazy Quilt Principle - Effectuation as the Inspiration for Developing Business Relations and Attitudes}

Streszczenie: Jedną z zasad efektuacyjnego podejścia do przedsiębiorczości jest zasada szalonego patchworku (crazy quilt), która dotyczy budowania relacji z otoczeniem biznesowym. Zgodnie z nią przedsiębiorca powinien korzystać $\mathrm{z}$ kontaktów z osobami z otoczenia, zbudowanych jeszcze przed założeniem firmy, a także aktywnie kształtować nowe relacje w środowisku, w którym firma działa. Silny networking i znajomość wielu osób pozwalają na czerpanie inspiracji i wspólne poszukiwanie nowych szans biznesowych. W artykule zaprezentowano wyniki badań ankietowych, których celem była ocena, na ile polscy przedsiębiorcy korzystają z zasady szalonego patchworku podczas realizacji celów swoich firm. Sprawdzono również, na ile studenci kierunku menedżerskiego doceniają wartość tej zasady, planując założenie własnej działalności gospodarczej. Wobec niewielkiego dorobku polskich badaczy dotyczącego efektuacji, zrealizowane badanie jest ważnym elementem budowania zasobów wiedzy z tego zakresu. Zgodnie z uzyskanymi wynikami, studenci okazali się w swoich przekonaniach bardziej zgodni z tradycyjnym, czyli przyczynowym (a nie efektuacyjnym) sposobem myślenia ze względu na wyraźną tendencję do rywalizowania, a nie kooperacji z konkurentami firmy. Efektem badań jest opracowanie katalogu rozwiązań, które powinny być włączone do procesu edukacji przedsiębiorczej, by uwrażliwiać obecnych i przyszłych przedsiębiorców na wartość budowanych relacji, a także wartości biznesowych $\mathrm{w}$ oparciu o stosunki interpersonalne $\mathrm{z}$ otoczeniem.

Abstract: One of the principles of the effectual approach to entrepreneurship is the crazy quilt principle focused on building relationships with the business environment. According to it, an entrepreneur should use contacts with people from the environment established before the founding of the company, as well as actively shape new relationships in the environment in which the company operates. Strong networking and relations with many people allow to gain inspiration and jointly search for new business opportunities. The article presents the results of surveys, whose purpose was to assess the extent to which 
Polish entrepreneurs use the crazy quilt principle. We also verified if students of a university's business faculty adopt the value of the principle when planning to set up their own business. Due to the fact that effectuation is still relatively under-researched in the Polish context, the current study offers an important contribution. According to the obtained results, students' thinking is more in line with the traditional - causal (and not effectual) logic. They display a clear tendency to compete rather than cooperate with the company's competitors. The result of the research is the development of a set of proposed solutions which might be included in entrepreneurial education. It highlights the importance of sensitising current and future entrepreneurs to the value of building relationships and achieving value through the process of utilising interpersonal relations.

Słowa kluczowe: edukacja przedsiębiorcza; efektuacja; networking; przedsiębiorczość; relacje biznesowe

Keywords: business relations; effectuation; entrepreneurial education; entrepreneurship

Otrzymano: 25 października 2019

Received: 25 October 2019

Zaakceptowano: 22 marca 2020

Accepted: 22 March 2020

Sugerowana cytacja/Suggested citation:

Krawczyk-Bryłka, B., Ziemiański, P., Tomczak, M.T., Stankiewicz, K. (2020). Zasada szalonego patchworku - efektuacja jako inspiracja do kształtowania relacji i postaw biznesowych. Przedsiębiorczość - Edukacja [Entrepreneurship - Education], 16(1), 225-236. doi: 10.24917/20833296.161.18

\section{Wstęp}

Efektuacja jest modelem przedsiębiorczości, który opisuje elastyczny, oportunistyczny, dynamiczny i iteracyjny proces tworzenia przedsięwzięcia biznesowego w warunkach wysokiej niepewności, z wykorzystaniem dostępnych zasobów, skoncentrowany na odkrywaniu potencjalnych efektów ich zastosowania (Sarasvathy, 2001). Cele przedsięwzięcia nie są więc jasno zdefiniowane, ale odkrywane i modyfikowane wraz z pozyskiwaniem nowych informacji, interesariuszy i pojawianiem się okoliczności rozumianych jako szanse biznesowe (Sarasvathy, Dew, 2005; Sarasvathy, 2008). Sposób działania efektuacyjnego przedsiębiorcy opisuje pięć reguł:

- zasada „wróbel w garści” (bird-in-hand) - przedsiębiorca koncentruje swoją uwagę na posiadanych zasobach, szukając możliwości wykorzystania ich dla tworzenia nowych rozwiązań biznesowych (zamiast poszukiwania zasobów koniecznych do realizacji wcześniej obranego celu);

- zasada „dopuszczalnej straty” (affordable loss) - zakres podejmowanego ryzyka wyznacza szacowanie dopuszczalnej straty, która może być zaakceptowana w procesie przedsiębiorczym (w opozycji do kalkulowania zwrotu z inwestycji);

- zasada „Zwariowanego patchworku” (crazy quilit) - otwartość przedsiębiorcy na każdego potencjalnego partnera biznesowego, który wyraża wolę współpracy, oraz korzystanie z jego potencjału przy określaniu i realizacji celów biznesowych (w przeciwieństwie do podejścia konkurującego);

- zasada „lemoniady” (lemonade principle) - przedsiębiorca dostrzega i traktuje pojawiające się sytuacje nieoczekiwane jako szanse biznesowe (nie unika ich i nie poprzestaje na adoptowaniu się do nich); 
- zasada "pilota w samolocie” (pilot-in-the-plane) - przejmowanie osobistej odpowiedzialności za wykorzystanie pojawiających się szans, postawa proaktywna (zamiast koncentrowania się na analizie trendów i śledzenia postępu technicznego).

Niniejszy artykuł koncentruje się na zasadzie szalonego patchworku, która dotyczy zakresu i sposobu budowania relacji przez efektuacyjnego przedsiębiorcę. By dobrze zrozumieć tę zasadę, warto wyjaśnić technikę patchworku, do którego odwołuje się zastosowana w nazwie metafora.

Stworzenie patchworku to technika misternego łączenia ze sobą niewielkich kawałków materiału, która nie wymaga zasobów finansowych, ponieważ wykonawca wykorzystuje dostępne resztki, ale obliguje wykonawcę do cierpliwej, długotrwałej pracy. Do kreowania patchworku potrzebne są odpowiednie narzędzia (igły, nici), ale przede wszystkim inwencja autora, pomysł na łączenie zgromadzonych wcześniej skrawków tkanin. Ważne, by materiały dobierać w sposób, który umożliwi ich późniejszą pielęgnację (na przykład nie łączyć wełny i tworzyw sztucznych), a także, aby zadbać o spójność kompozycji pod względem grubości i ciężaru tkanin, co podnosi użyteczność i estetykę przygotowanego produktu. Przygotowanie patchworku nie jest więc procesem chaotycznym, zakłada staranne przygotowanie, zaangażowanie własnej kreatywności oraz nastawienie na określony cel, jakim jest produkt użytkowy (np. kołdra czy odzież) (Singht, Davidson, 2016). Wykorzystany w nazwie zasady szalonego patchworku w wersji anglojęzycznej wyraz quilt, oznacza pikowany patchwork, którego efekt zależy od zachowania odpowiednich proporcji zszywanych elementów oraz spójności ostatecznej kompozycji (Daniel, 2008).

Wyjaśniając zasadę szalonego patchworku i znaczenia relacji w rozwijaniu biznesowych przedsięwzięć, badacze koncepcji efektuacji zalecają przedsiębiorcom otwartość na każdą znajomość, tłumacząc, że w danym momencie trudno przewidzieć, na ile poznana lub polecona osoba wpłynie na budowanie wartości biznesu (Read et all, 2016). Efektuacyjne budowanie relacji to wychodzenie $\mathrm{z}$ inicjatywą i dostrzeganie wartości każdego „kawałka materiału”, każdego fragmentu sieci, który po włączeniu w całość kompozycji tworzy otoczenie biznesowe skomponowane według potrzeb przedsiębiorcy. Dołączanie kolejnych partnerów do sieci jest procesem ciągłym, wymagającym aktywności i cierpliwości w pozyskiwaniu zainteresowania potencjalnych partnerów. To również proces kreatywny, którego efekt końcowy nie zawsze jest możliwy do przewidzenia, ale zawsze jest zależny od zgromadzonych „skrawków”, czyli poszczególnych osób. Pikowanie to wkład w spójność sieci i utrwalanie tych znajomości, które rzeczywiście skutkują innowacyjnymi rozwiązaniami.

Trudno znaleźć odpowiedź na pytanie, dlaczego S.D. Sarasvathy (2001) nazwała zasadę dotyczącą budowania relacji regułą szalonego patchworku. Może dlatego, że w odróżnieniu od typowej techniki patchworku pomysł na ostateczny efekt pojawia się w trakcie trwania procesu, nie jest z góry zaplanowany. Nieprzewidywalność relacji efektuacyjnych określa ich główne cechy: bardzo wysoki poziom niepewności, który paradoksalnie sprzyja wspólnemu redukowaniu niepewności biznesowej, zaufanie, które skutkuje wolą inwestowania w relacje w granicach założonej straty, oraz tworzenie sieci relacji - otwartość na zmiany i rozwój w łańcuchu wzajemnych zależności (Galkina, Chetty, 2015). Możliwe jest również, że za „szalone” autorka koncepcji uznała właśnie dołączanie do sieci kontaktów osób napotykanych na różnych etapach działania przedsiębiorcy, nieograniczanie się do raz zgromadzonych zasobów, ale elastyczne zmienianie celu w zależności od pojawiających się szans i zainteresowanie pozornie niepasującymi do całości elementami. 
Orientacja na budowanie sieci relacji jest uważana za integralną część efektuacji (Yrjönkoski, Suominen, 2018). Ważność zasady szalonego patchworku powoduje zaś, że model efektuacyjny uważa się za krok przejścia z indywidualnego rozumienia przedsiębiorczości na poziom sieciowy, gdzie relacje są jednym z głównych źródeł odkrywania możliwości biznesowych (Kerr, Coviello, 2019). Budowane sieci relacji są z jednej strony podstawą efektuacyjnego działania, a z drugiej - również efektem efektuacyjnego, proatywnego postrzegania szans (zasada lemoniady i pilota w samolocie). Specyfikę efektuacyjnych relacji zaprezentowano w kolejnej części artykułu.

\section{Relacje biznesowe w efektuacyjnym modelu przedsiębiorczości}

Zasada szalonego patchworku zakłada korzystanie z relacji nawiązanych przez przedsiębiorcę. Opiera się ona na filozofii partnerstwa i wzajemnego zaangażowania stron w kreowanie szans biznesowych (Kerr, Coviello, 2019). Pisząc o efektuacyjnych relacjach, Saraswathy (2008) odwołuje się do metafory ciasta, którego partnerzy nie dzielą między siebie, ale je współtworzą, eksperymentują z nim, chociaż nie do końca są w stanie przewidzieć, jaki będzie efekt wspólnego zaangażowania i jak będzie można się nim podzielić. Strony uczestniczące w budowaniu sieci relacji współpracują w kształtowaniu przedsięwzięcia, nawet jeśli ostatecznie nie będą partycypować w jego rozwoju i zyskach. Uczestnicy relacji nie są zainteresowani, jaka część przygotowanego ciasta przypadnie im w udziale, ale koncentrują się na tym, jaki będzie jego kształt, zawartość czy zapach (Sarasvathy, Dew, 2003). Zawieranie aliansów i ustalanie z interesariuszami poszczególnych wymiarów przyszłego działania, nie tylko ogranicza niepewność, ale też wzmacnia ich potencjalne zaangażowanie $\mathrm{w}$ realizację wykreowanych przez przedsiębiorcę wizji. Taka postawa zmniejsza zainteresowanie analizami działań konkurencji, tym bardziej, że brak jasno określonego celu utrudnia wybór konkretnego rynku do takich analiz. „Doszywanie” kolejnych elementów do patchworkowej sieci relacji powoduje, że wśród pozyskanych partnerów pojawią się klienci lub współpracownicy bez ponoszenia ogromnych kosztów badań marketingowych. Współpraca, dzięki wykorzystaniu różnorodności partnerów, decyduje o ostatecznym efekcie działań przedsiębiorczych (Murdock, Varnes, 2017). Sieci społeczne należą do zasobów przedsiębiorcy, które ze względu na gotowość współzależności ze strony partnerów biznesowych mogą stanowić o możliwościach powiększania potencjału i wykorzystania pojawiających się możliwości (Duliniec, 2017).

Co odróżnia relacje budowane zgodnie z założeniami efektuacji od tradycyjnych, kształtowanych i cenionych przez wszystkich przedsiębiorców, również tych działających typowo kauzalnie? W tabeli 1 przedstawiono listę cech charakterystycznych dla efektuacyjnych sieci biznesowych w kontraście z tradycyjnymi relacjami.

Cel i sposób budowania efektuacyjnych relacji bywa porównywany do koopetycji, która może mieć dwa oblicza. Pierwsze to celowo budowana strategia kształtowania relacji przez podejmowanie menedżerskich decyzji o współpracy pomiędzy konkurencyjnymi podmiotami. Drugi wymiar koopetycji to współpraca intuicyjna, spontaniczna, pojawiająca się pod wpływem czynników zewnętrznych, która ostatecznie może napędzać wspólne budowanie wartości i odkrywanie szans oraz innowacyjnych rozwiązań przez współdziałających konkurentów - tu widoczne są odwołania do zasady szalonego patchworku (Galkina, Lundgren-Henriksson, 2017). 
Co więcej, koopetycja, podobnie jak efektuacja, opiera się na partnerskim dzieleniu się wiedzą, służy redukcji ryzyka i najlepiej sprawdza się w warunkach wysokiej niepewności. Efektuacyjna współpraca w koopetycji zakłada budowanie sieci z szerokim gronem interesariuszy, których łączy wysoki poziom zaangażowania, nastawiony na generowanie różnych rozwiązań, a niekoniecznie na określony wcześniej cel, oraz wysoki poziom wzajemnego zaufania. Próba koordynacji tych relacji bywa bezcelowa, gdyż stale zmieniające się otoczenie i brak jasno określonego celu powodują, że uczestnicy koncentrują się raczej na wspólnym, dynamicznym kreowaniu innowacji.

Tabela 1. Porównanie efektuacyjnych relacji biznesowych z kauzalnymi

\begin{tabular}{|c|c|c|}
\hline \multirow{2}{*}{$\begin{array}{l}\text { Aspekty } \\
\text { relacji }\end{array}$} & \multicolumn{2}{|c|}{ Model przedsiębiorczości } \\
\hline & efektuacyjny & kauzalny \\
\hline Cel & $\begin{array}{l}\text { - Radzenie sobie z sytuacją } \\
\text { niepewności, brakiem informacji } \\
\text { - Wzrost elastyczności i kosztów } \\
\text { eksperymentowania. Pozyskiwanie } \\
\text { kooperantów bez jasno } \\
\text { sprecyzowanego celu biznesowego, } \\
\text { na etapie szukania pomysłów } \\
\text { - Przekształcanie niepewności w szanse } \\
\text { biznesowe } \\
\text { - Motywacja o charakterze społecznym }\end{array}$ & $\begin{array}{l}\text { - Świadome, strategiczne dobieranie } \\
\text { kooperantów, którzy zwiększą } \\
\text { szanse na realizację założonego celu } \\
\text { i osiągnięcie oraz maksymalizację } \\
\text { określonego } \\
\text { - Motywacja instrumentalna }\end{array}$ \\
\hline $\begin{array}{l}\text { Sposób } \\
\text { budowania }\end{array}$ & $\begin{array}{l}\text { - Nawiązywanie relacji w różnych } \\
\text { okolicznościach z przypadkowymi } \\
\text { osobami: każdy z otoczenia może } \\
\text { stać się potencjalnym wsparciem } \\
\text { w odkrywaniu szans biznesowych } \\
\text { - Rozpoczynanie budowania sieci } \\
\text { kontaktów od najbliższego otoczenia } \\
\text { - Stałe zauważanie nowych } \\
\text { interesariuszy, którzy są źródłem } \\
\text { pomysłów, rozwiązań, kokreatorami } \\
\text { przedsięwzięcia } \\
\text { - Iteracyjne spotkania i negocjacje, } \\
\text { skoncentrowane są na } \\
\text { charakterystyce podejmowanych } \\
\text { projektów, preferencjach, } \\
\text { oczekiwaniach, rolach (mniej } \\
\text { na zysku) } \\
\text { - Możliwość wzajemnej promocji } \\
\text { stron, wspierania się } \\
\text { - Kompetencje stron, homogeniczność } \\
\text { i zaufanie są podstawą relacji }\end{array}$ & $\begin{array}{l}\text { - Dostosowane do etapu } \\
\text { funkcjonowania organizacji. } \\
\text { Kształtowanie kontaktów opartych } \\
\text { na celowych strategiach identyfikacji, } \\
\text { negocjacji i selekcji kooperantów } \\
\text { (również zaprzestanie relacji, } \\
\text { gdy przestaje ona służyć celom } \\
\text { przedsiębiorcy) } \\
\text { - W negocjacjach koncentracja } \\
\text { na podziale zysku i władzy } \\
\text { - Podstawą relacji jest możliwa } \\
\text { wymiana (dóbr, informacji, wsparcia) } \\
\text { - Ważne dla relacji są kompetencje } \\
\text { stron, wzajemne zaufanie, a także } \\
\text { wzajemne współzależności } \\
\text { i dystrybucja władzy }\end{array}$ \\
\hline
\end{tabular}

Źródło: opracowanie własne na podstawie: Kerr, Coviello (2019: 374-377)

Już w 2015 r. zainicjowano w Polsce efektuacyjną politykę przedsiębiorczości, której ważnym założeniem było wykorzystanie zasady szalonego patchworku przez promocję instrumentów angażujących przedsiębiorców do dzielenia się wiedzą i doświadczeniami $\mathrm{z}$ adeptami biznesu (Cieślik, 2015). Efektuację uważa się też za istotny model kształtowania 
innowacyjnych przedsiębiorców (Cieślik, Skala, 2016). Poniższe badanie pokazuje, na ile te założenia są wdrażane w działaniach przedsiębiorczych i na ile są one cenione przez studentów - potencjalnych przedsiębiorców.

\section{Zasada szalonego patchworku w praktyce przedsiębiorczej i w ocenie studentów - badania własne}

Celem prezentowanych badań była ocena, czy zasada szalonego patchworku jest realizowana w praktyce prowadzenia firmy przez przedsiębiorców oraz czy jest ona istotna w ocenie studentów, którzy przygotowują się do prowadzenia własnej działalności gospodarczej. Badaniem objęto dwie grupy: 107 przedsiębiorców (P), których firmy funkcjonują w województwie pomorskim, oraz 70 studentów (S), którzy byli na specjalności związanej z przedsiębiorczością na II stopniu studiów. Zastosowano kwestionariusz, w którym wśród wielu stwierdzeń dotyczących zachowań przedsiębiorczych umieszczono 5 stwierdzeń odzwierciedlających działania zgodne z zasadą szalonego patchworku:

- (EFE 1) Aktywnie budujemy i utrzymujemy sieć kontaktów biznesowych, wykorzystujemy różne okazje, by budować relacje.

- (EFE 2) Partnerzy biznesowi naszej firmy są dla niej źródłem potencjalnych szans na rozwój biznesu.

- (EFE 3) Kierując naszą firmą, jesteśmy gotowi zwracać się do innych (firm) o wsparcie.

- (EFE 4) Wspieramy znajome firmy, na przykład polecając je innym.

- (EFE 5) Rozwijając biznes, korzystamy z relacji rodzinnych i wśród znajomych. Dwa kolejne stwierdzenia charakteryzowały tradycyjny model przedsiębiorczości:

- (KAZ 1) Szukamy partnerów biznesowych pośród tych, którzy zapewnią zysk ze współpracy.

- (KAZ 2) Analizujemy działania konkurencji, aby z nią wygrywać.

Wyboru stwierdzeń dokonano na podstawie przeprowadzonej wcześniej analizy poznawczych i behawioralnych wskaźników modelu mentalnego przedsiębiorczości, którą zaprezentowano we wcześniejszym opracowaniu autorów (Krawczyk-Bryłka i in., 2018). Każdej z grup badawczych postawiono inne pytanie: przedsiębiorcy oceniali, na ile podane stwierdzenia opisują działania prowadzonej przez nich firmy, zaś studenci opiniowali, na ile poszczególne stwierdzenia są ważne dla efektywnego prowadzenia własnej firmy. Odpowiedzi udzielano w pięciostopniowej skali, gdzie 1 oznaczało, że dane stwierdzenie nie pasuje do prowadzonej / efektywnej firmy, zaś 5 oznaczało, że dane stwierdzenie bardzo dobrze pasuje do prowadzonej / efektywnej firmy.

Porównanie średnich wyników uzyskanych w grupie przedsiębiorców i studentów wskazuje na różnice w ocenie poszczególnych stwierdzeń (rycina 1). Przedsiębiorcy wskazali, że najczęściej realizowaną przez nich zasadą dotyczącą budowania relacji z otoczeniem jest traktowanie partnerów biznesowych firmy jako źródła potencjalnych szans na rozwój biznesu (EFE 2), gdzie średni wynik wyniósł 4,06. Według studentów najważniejszą zasadą, zapewniającą efektywność prowadzonej firmy, jest z kolei aktywne budowanie i utrzymywanie sieci kontaktów biznesowych i wykorzystywanie różnych okazji, by budować relacje (EFE 1); średnia wyniosła 4,49. Za najrzadziej aplikowaną przez właścicieli firm i najmniej istotną przez studentów została uznana zasada EFE 5: korzystanie $\mathrm{z}$ relacji rodzinnych i wśród znajomych dla rozwoju biznesu (średnie: P: 3,45, S: 3,27). 
Rycina 1. Średnie wyniki w obu grupach dla poszczególnych stwierdzeń

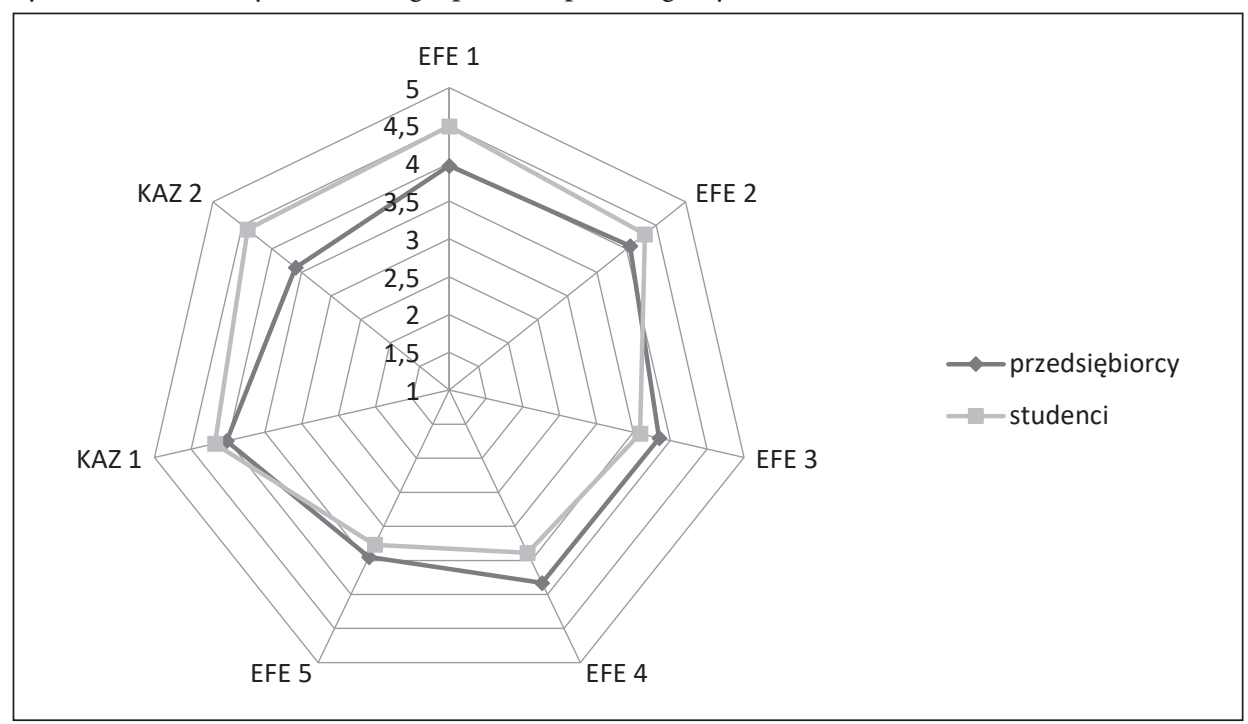

Źródło: opracowanie własne

Różnice statystycznie istotne dotyczą trzech stwierdzeń: EFE 1, EFE 4 i KAZ 2 (tabela 2). Studenci zdecydowanie wyżej ocenili znaczenie efektuacyjnej reguły dotyczącej aktywności w budowaniu i utrzymywaniu relacji oraz kauzalnej zasady konkurowania $\mathrm{z}$ innymi podmiotami $\mathrm{w}$ otoczeniu biznesowym $\mathrm{w}$ porównaniu $\mathrm{z}$ aplikowalnością tych zasad w firmach prowadzonych przez badanych przedsiębiorców.

Tabela 2. Porównane średnich wyników dla poszczególnych stwierdzeń (podano wyniki istotne statystycznie, analiza testem T-studenta)

\begin{tabular}{|c|c|c|c|c|c|}
\hline \multicolumn{2}{|c|}{ Zasady } & Średnia P & Średnia S & $\mathbf{p}$ & $\mathbf{t}$ \\
\hline \multirow{6}{*}{ EFE } & 1 & 3,97 & 4,49 & $<0,01$ & $-3,78$ \\
\hline & 2 & 4,06 & 4,31 & & \\
\hline & 3 & 3,85 & 3,59 & & \\
\hline & 4 & 3,83 & 3,39 & $<0,01$ & $-2,77$ \\
\hline & 5 & 3,45 & 3,27 & & \\
\hline & razem & 3,83 & 3,81 & - & - \\
\hline \multirow{3}{*}{ KAZ } & 1 & 4,02 & 4,18 & & \\
\hline & 2 & 3,60 & 4,41 & $<0,01$ & $-5,40$ \\
\hline & razem & 3,81 & 4,3 & - & - \\
\hline
\end{tabular}

Źródło: opracowanie własne

Ciekawe jest również porównanie średnich uzyskanych przez obie grupy dla kategorii zachowań efektuacyjnych i kauzalnych (uśrednione wyniki otrzymane dla wszystkich stwierdzeń z danej grupy stwierdzeń). O ile średnia dotycząca zachowań efektuacyjnych nie różni się (P: 3,83, S: 3,81), o tyle średnie wyniki w kategorii działań kauzalnych są zdecydowanie wyższe w grupie studentów (P: 3,81, S: 4,3). 
Efektuacyjna edukacja przedsiębiorczości - wnioski i rekomendacje

Efektuacja jest uważana za alternatywny wobec tradycyjnego model przedsiębiorczości, najczęściej będący podstawą edukacji przedsiębiorczej (Günzel-Jensen, Robinson, 2016). Kształcenie przyszłych przedsiębiorców oparte o zasady efektuacji stanowi wyzwanie edukacyjne, dotyczące włączania elementów efektuacji do programu kształcenia, ale również stosowania metod, które będą służyć rozwijaniu efektuacyjnego myślenia.

Edukacja przedsiębiorcza może być realizowana na trzy sposoby: edukacja o przedsiębiorczości, edukacja dla przedsiębiorczości i edukacja poprzez przedsiębiorczość (Jones i inni, 2014). Jeśli kształcenie ma się opierać na efektuacyjnym modelu, w którym przedsiębiorczość jest procesem skoncentrowanym na korzystaniu z osobistych zasobów oraz relacji z szeroko rozumianym otoczeniem biznesowym i iteracyjnym uczeniu się, edukacja musi mieć również charakter procesowy, być spersonalizowana i opierać się głównie na uczeniu poprzez doświadczanie przedsiębiorczości (Günzel-Jensen, Robinson, 2017). Jest to wyzwanie, szczególnie gdy dotyczy niedoświadczonych studentów, gdyż napotyka na trzy bariery:

- Brak doświadczeń i niska świadomość własnych kompetencji przedsiębiorczych skutkują trudnościami w korzystaniu z własnych zasobów przez uczących się studentów, zaś ich nastawienie na kauzalne realizowanie określonych celów skutkuje podejrzliwością wobec założeń efektuacji;

- Realizacja projektów przedsiębiorczych stworzonych tylko dla potrzeb edukacyjnych utrudnia wybór i przekonanie do współpracy osób z otoczenia biznesowego (które jest trudne do zdefiniowania przy „sztucznych” projektach);

- Rola nauczyciela przedsiębiorczości zmienia się z osoby przekazującej wiedzę na promotora efektuacyjnych postaw i animatora innowacyjności. W przypadku braku praktyki przedsiębiorczej może obniżać wiarygodność w oczach studentów i wymusza stosowanie interaktywnych metod nauczania, skoncentrowanych na odkrywaniu potencjału własnego przez uczestników kursu.

Szczególnie druga z wymienionych barier wskazuje, jak trudne może być kształcenie dotyczące zasady szalonego patchworku. Gdy realizowany w czasie zajęć projekt ma charakter laboratoryjny i nie skutkuje założeniem realnej firmy, trudno pozyskać i przekonać do współpracy inne osoby i firmy, realnie funkcjonujące na rynku. Za celowe można uznać zatem angażowanie młodych ludzi w projekty, które mają cechy projektu przedsiębiorczego (jak np. elementy nowości, ryzyka i niepewności oraz konieczność zaangażowania dodatkowych osób czy organizacji). Projekty tego typu mają w sobie potencjał zastępowania realnych działań przedsiębiorczych i, choć nie są ich dokładnym odpowiednikiem, pozwalają na rozwijanie kompetencji, które później mogą być wykorzystane w prowadzeniu własnej działalności, czy też w ramach przedsiębiorczości wewnętrznej realizowanej w organizacji. Takim projektem może być dla studentów uczelni wyższej organizacja konferencji czy wydarzenia, na które zaprosiliby osoby będące ekspertami w swojej dziedzinie, a których poznanie mogłoby stanowić element budowania przez studentów sieci relacji zawodowych (posiłkując się tytułem niniejszego artykułu, byłby to element ich szalonego patchworku). Ważne jest, że wykonując takie zadanie w zespole, studenci mają szansę na poznanie własnych kompetencji, uczą się oceniać kapitał społeczny zespołu i dobierać osoby do współpracy zgodnie z ważnymi kryteriami. Jednym z nich, na które warto zwrócić uwagę w procesie dydaktycznym, jest potencjał osoby do budowania relacji: kogo znam, 
kogo mogę zaangażować dla budowania wartości przedsięwzięcia. Konieczna jest tu zmiana podejścia do korzystania ze zbudowanych relacji - w Polsce działanie „po znajomości” budzi historycznie niekorzystne skojarzenia, co może ograniczać otwartość na rozwijanie sieci biznesowych kontaktów. Przewartościowanie wynikające ze stosowania reguły szalonego patchworku i koopetycji wymaga więc promocji, a jednocześnie akcentowania zasad etyk i fair play w postępowaniu z partnerami biznesowymi.

Korzystnym działaniem byłoby włączenie do zajęć dydaktycznych i kursów mających rozwijać kompetencje przedsiębiorcze informacji, czym jest szalony patchwork, a także wyników badań opisanych w niniejszym artykule. Przede wszystkim warto pokazać studentom, w jakim zakresie ich wyobrażenia dotyczące funkcjonowania skutecznych przedsiębiorców są nie do końca spójne z tym, co deklarują osoby prowadzące własną działalność, a w jakim się ze sobą zazębiają. Z uzyskanych wyników można wyciągnąć wniosek, że przedsiębiorcy (w kontraście do przekonań studentów) w większym stopniu angażują się $\mathrm{w}$ rekomendowanie firm, $\mathrm{z}$ którymi współpracują, a w mniejszym - w analizowanie konkurencji, żeby osiągać nad nią przewagę. Analiza historii efektywnych przedsiębiorców, stosowania przez nich zasad efektuacji, w tym zasady szalonego patchworku, może być impulsem do zmiany nastawienia wobec otoczenia biznesowego. Idealnym rozwiązaniem jest stwarzanie studentom możliwości spotkania takich osób, które mówiąc o źródłach biznesowego sukcesu, zwracają uwagę na budowanie partnerskich, korzystnych relacji z innymi firmami. Zorganizowanie spotkania z nimi mogłoby być wspomnianym wcześniej przedsiębiorczym projektem studenckim. Bardziej wymagającą formą kształcenia postaw przedsiębiorczych są programy mentoringowe, które opierają się na relacji mentorowanego z mentorem, co już samo w sobie stanowi sposób na budowanie biznesowych sieci współpracy, ale również pozwala na wprowadzanie początkującego przedsiębiorcy w środowisko biznesowe na podstawie rekomendacji mentora.

W odniesieniu do charakterystyki pokoleń (Y i Z), które reprezentują studenci przygotowywani do aktywności przedsiębiorczej warto w kontekście zasady szalonego patchworku zwrócić uwagę na aspekt budowania własnego wizerunku i nawiązywania relacji w internecie. Na przykład aktywność w mediach społecznościowych powinna być wskazywana jako szansa na wykorzystanie relacji budowanych online jako potencjalnego środowiska przyszłej działalności przedsiębiorczej: promocję samego siebie przez budowanie osobistej marki, wizerunku osoby kompetentnej, zmotywowanej, jak również nawiązywanie kontaktów z osobami działającymi w różnych obszarach.

Literatura

References

Cieślik, J. (2015). Jaka polityka przedsiębiorczości? Alert, 4, 1-5.

Cieślik, J., Skala, A. (2016). Nowe tendencje w kształceniu innowacyjnych przedsiębiorców. Horyzonty Wychowania, 15(34), 309-322. doi: 10.17399/HW.2016.1534018.

Daniel, N.B. (2008). The Art of the Handmade Quilt. New York/London: Sterling Publishing Company. Duliniec, E. (2017). Efektuacja, marketing przedsiębiorców i wczesna internacjonalizacja przedsiębiorstw. Marketing i Rynek, 9, 83-89.

Galkina, T., Chetty, S. (2015). Effectuation and Networking of Internationalizing SMEs, Management International Review, 55, 647-676. doi: 10.1007/s11575-015-0251-x. 
Galkina, T., Lundgren-Henriksson, E.L. (2017). Coopetition as an entrepreneurial process: Interplay of causation and effectuation. Industrial Marketing Management, 67, 158-173. doi: http://dx.doi. org/10.1016/j.indmarman.2017.09.004

Günzel-Jensen, F., Robinson, S. (2017). Effectuation in the undergraduate classroom: three barriers to entrepreneurial learning. Education + Training, 59(7/8), 780-797. doi: 10.1108/ET-03-2016-0049

Jones, C., Matley, H., Penalula,K., Penalula, A. (2014). Claiming the future of enterprise education. Education + Training, 56(8/9), 764-775. doi: 10.1108/ET-06-2014-0065

Kerr, J., Coviello, N. (2019). Formation and Constitution of Effectual Networks: A systematic Review and Synthesis. International Journal of Management Reviews, 21, 370-397. doi: 10.1111/ijmr.12194

Krawczyk-Bryłka, B., Stankiewicz, K., Tomczak, M., Ziemiański, P. (2018). Modele mentalne przedsiębiorczości: wskaźniki efektuacyjne vs kauzalne. Przedsiębiorczość i Zarządzanie, vol. XIX(10/II), 215-229.

Murdock, K., Varnes, C.J. (2018). Beyond Effectuation: Analysing the Transformation of Business Ideas into Ventures Using Actor-network Theory. International Journal of Entrepreneurial Behavior \& Research, 24(1), 256-272. doi: 10.1108/IJEBR-01-2017-0039.

Sarasvathy, S. (2001). Toward Causation and Effectuation: A Theoretical Shift From Inevitability to Economic Entrepreneurial Contingency. The Academy of Management Review, 26(2), 243-263. doi: $10.2307 / 259121$

Read, S., Sarasvathy, S., Dew, N., Wiltbank, R. (2016). Effectual entrepreneurship. London: Routledge.

Sarasvathy, S.D. (2008). Effectuation: Elements of entrepreneurial expertise. Cheltenham: Edward Elgar Publishing.

Sarasvathy, S.D., Dew, N. (2003). Effectual Networks: A pre-commitment approach to bridging the gap between opportunism and trust. https://www.effectuation.org/wp-content/uploads/2016/06/ aom-03-effectual-networks-1.pdf

Sarasvathy, S.D., Dew, N. (2005). New market creation through transformation. Journal of evolutionary economics, 5(15), 533-565. doi: 10.1007/s00191-005-0264-x

Singh, J, Davidson, J. (2016). Learning Patchwork - traditional patchwork techniques. Mendon Cottage Books. UK: Edward Elgar.

Yrjönkoski, K., Suominen, A. (2018). Effectuation as a frame for networking decisions - the case of a Finnish information technology start-up. Proceedings-of-International-Workshop-on-Softwareintensive-Business-Start-ups-Ecosystems and Platforms (SiBW). Espoo, Finland, 230-244.

Beata Krawczyk-Bryłka, dr, Politechnika Gdańska, Wydział Zarządzania i Ekonomii. Psycholog, doktor nauk humanistycznych $\mathrm{w}$ dziedzinie zarządzania, adiunkt w Katedrze przedsiębiorczości i prawa gospodarczego. Jej zainteresowania badawcze koncentrują się wokół zagadnień dotyczących zarządzania zespołami wirtualnymi, zarządzania zaufaniem w zespołach, psychologicznych aspektów przedsiębiorczości oraz zespołów przedsiębiorczych. Kierownik projektu NCN: „Efektuacyjny model zespołu przedsiębiorczego. Jak działają przedsiębiorcze zespoły odnoszące sukces”. Quality Lead filaru People management \& personal development na studiach MBA Politechniki Gdańskiej, w latach 2008-2012 prodziekan ds. kształcenia. Członek Gdańskiego Towarzystwa Naukowego i Polskiego Stowarzyszenia Psychologii Organizacji.

Beata Krawczyk-Bryłka, PhD, Gdansk University of Technology, Faculty of Management and Economics. Psychologist, PhD in management, assistant professor in the Department of Entrepreneurship and Business Law. She is interested in virtual team management, team trust management, psychological aspects of entrepreneurship and entrepreneurial teams. Leader of the project: "Effectuation model of entrepreneurial teams. How do effective entrepreneurial teams operate?" founded by the NSC. Quality Lead of People management \& personal development in International MBA GUT programme, in 2018-2012 Vice Dean for education. Member of The Scientific Society of Gdańsk and Polish Association of Organizational Psychology.

ORCID: https://orcid.org/0000-0001-7677-9549 


\section{Adres/Address:}

Politechnika Gdańska

Wydział Zarządzania i Ekonomii

ul. Narutowicza 11/12

80-233 Gdańsk, Polska

e-mail: beabrylk@pg.edu.pl

Michał T. Tomczak, dr nauk społecznych, Politechnika Gdańska, Wydział Zarządzania i Ekonomii. Jego zainteresowania badawcze koncentrują się wokół problematyki zarządzania zasobami ludzkimi, a w szczególności kompetencji pracowników oraz technologii wspomagających integrację osób ze spektrum zaburzeń autystycznych w cyfrowym środowisku pracy. Koordynator Zespołu ds. Monitorowania Losów Zawodowych Absolwentów PG, kierownikiem Studiów Podyplomowych Menedżer HR oraz Zarządzanie Samorządem Terytorialnym. Kierownik i wykonawca w kilku projektach finansowanych z Narodowego Centrum Nauki oraz Narodowego Centrum Badań i Rozwoju. Autor artykułów w czasopismach naukowych, rozdziałów w monografiach, raportów z badań oraz podręcznika z zakresu zarządzania zasobami ludzkimi. Członek Gdańskiego Towarzystwa Naukowego oraz ekspert Narodowej Agencji Wymiany Akademickiej (NAWA).

Michał T. Tomczak, PhD in social sciences, Gdańsk University of Technology, Faculty of Management and Economics. His research interests focus on Human Resources Management, particularly on employees' competencies and Assistive Technologies integrating employees with Autism Spectrum Disorders within the digitized workplace. Head of Research Team in the field of GUT Graduates Professional Situation Monitoring and head of HR Manager and Local Self-Government Management postgraduate programs. Project leader and researcher in several research projects financed by the National Science Centre and the National Centre for Research and Development. Author of articles in journals, chapters in monographs, research reports and Human Resources Management Handbook for University Students. Member of the Scientific Society of Gdańsk and expert of Polish National Agency for Academic Exchange (NAWA).

ORCID: https://orcid.org/0000-0002-2916-5015

\section{Adres/Address:}

Politechnika Gdańska

Wydział Zarządzania i Ekonomii

ul. Narutowicza 11/12

80-233 Gdańsk, Polska

e-mail: michal.tomczak@zie.pg.edu.pl

Katarzyna Stankiewicz, dr, Politechnika Gdańska, Wydział Zarządzania i Ekonomii. Psycholog, dr nauk społecznych w dziedzinie psychologii. Jej zainteresowania badawcze koncentrują się wokół problematyki zarządzania zespołami zróżnicowanymi, psychologicznych uwarunkowań efektywności pracy zespołów i psychologicznych aspektów przedsiębiorczości.

Katarzyna Stankiewicz, PhD, Gdansk University of Technology, Faculty of Management and Economics. Psychologist, $\mathrm{PhD}$ in psychology. Her research interests focus on diverse team management, psychological determinants of teamwork effectiveness and psychological aspects of entrepreneurship.

ORCID: https://orcid.org/0000-0002-97807702 
Adres/Address:

Politechnika Gdańska

Wydział Zarządzania i Ekonomii

ul. Narutowicza 11/12

80-233 Gdańsk, Polska

e-mail: katarzyna.stankiewicz@zie.pg.gda.pl

Paweł Ziemiański, dr, Politechnika Gdańska, Wydział Zarządzania i Ekonomii. Psycholog, doktor nauk społecznych w dziedzinie psychologii, adiunkt w Katedrze Przedsiębiorczości i Prawa Gospodarczego. Jego zainteresowania badawcze dotyczą przedsiębiorczych zespołów, przedsiębiorczego poczucia samoskuteczności oraz efektuacji jako sposobu podejmowania decyzji przez indywidualnych przedsiębiorców oraz tych, którzy działają w zespołach. Zajmuje się także psychologicznymi aspektami sprawowania władzy w organizacjach.

Paweł Ziemiański, PhD, Gdansk University of Technology, Faculty of Management and Economics. Psychologist, $\mathrm{PhD}$ in psychology, assistant professor in the Department of Entrepreneurship and Business Law. His research interests include entrepreneurial teams, entrepreneurial self-efficacy and effectuation as a framework of decisions (made by individual entrepreneurs, as well as those who operate in teams). He is also interested in psychological aspects of holding power in organisations.

ORCID: https://orcid.org/0000-0002-4391-9282

Adres/Address:

Politechnika Gdańska

Wydział Zarządzania i Ekonomii

ul. Narutowicza 11/12

80-233 Gdańsk, Polska

e-mail: pawel.ziemianski@zie.pg.gda.pl

Artykuł powstał w ramach projektu badawczego: „Efektuacyjny model zespołu przedsiębiorczego. Jak działają przedsiębiorcze zespoły odnoszące sukces?” finansowanego przez NCN w ramach konkursu Opus 13 (UMO-2017/25/B/ HS4/01507). 